\title{
Concentrations and sources of polycyclic aromatic hydrocarbons in surface coastal sediments of the northern Gulf of Mexico
}

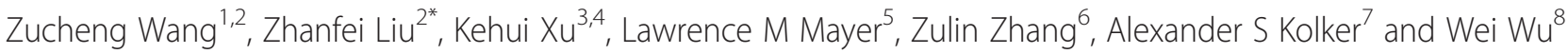

\begin{abstract}
Background: Coastal sediments in the northern Gulf of Mexico have a high potential of being contaminated by petroleum hydrocarbons, such as polycyclic aromatic hydrocarbons (PAHs), due to extensive petroleum exploration and transportation activities. In this study we evaluated the spatial distribution and contamination sources of PAHs, as well as the bioavailable fraction in the bulk PAH pool, in surface marsh and shelf sediments (top $5 \mathrm{~cm}$ ) of the northern Gulf of Mexico.
\end{abstract}

Results: PAH concentrations in this region ranged from 100 to $856 \mathrm{ng} \mathrm{g}^{-1}$, with the highest concentrations in Mississippi River mouth sediments followed by marsh sediments and then the lowest concentrations in shelf sediments. The PAH concentrations correlated positively with atomic $\mathrm{C} / \mathrm{N}$ ratios of sedimentary organic matter $(\mathrm{OM})$, suggesting that terrestrial OM preferentially sorbs PAHs relative to marine OM. PAHs with 2 rings were more abundant than those with 5-6 rings in continental shelf sediments, while the opposite was found in marsh sediments. This distribution pattern suggests different contamination sources between shelf and marsh sediments. Based on diagnostic ratios of PAH isomers and principal component analysis, shelf sediment PAHs were petrogenic and those from marsh sediments were pyrogenic. The proportions of bioavailable PAHs in total PAHs were low, ranging from $0.02 \%$ to $0.06 \%$, with higher fractions found in marsh than shelf sediments.

Conclusion: PAH distribution and composition differences between marsh and shelf sediments were influenced by grain size, contamination sources, and the types of organic matter associated with PAHs. Concentrations of PAHs in the study area were below effects low-range, suggesting a low risk to organisms and limited transfer of PAHs into food web. From the source analysis, PAHs in shelf sediments mainly originated from direct petroleum contamination, while those in marsh sediments were from combustion of fossil fuels.

Keywords: Polycyclic aromatic hydrocarbons, Grain size, Surface area, Organic carbon, Principal component analysis, Bioavailability, Coastal sediments, Northern Gulf of Mexico

\section{Introduction}

As a major group of persistent organic pollutants, polycyclic aromatic hydrocarbons (PAHs) are widely found in natural environments. The geochemical behaviors of PAHs have been widely studied because of their carcinogenic, mutagenic and persistent properties [1-6]. Determining PAH concentrations in coastal and oceanic sediments is necessary for risk assessment and evaluation of ecosystem health $[3,7,8]$. PAHs in the environment are petrogenic and

\footnotetext{
* Correspondence: zhanfei.liu@utexas.edu

${ }^{2}$ Marine Science Institute, The University of Texas at Austin, Port Aransas, TX, USA Full list of author information is available at the end of the article
}

pyrogenic, which affects their composition and bioavailability. For example, PAHs sourced from oil are more bioavailable than those from coal [9]. In coastal environments most PAHs derive from petroleum spillage, industrial discharges, atmospheric deposition, and urban run-off [10]. PAHs in the environment may be sorbed onto particles and deposited into sediments due to their highly hydrophobic nature [11-13]. The strong adsorption of PAHs to sediment particles may lead to their low bioavailability and biodegradation rate, preserving them in sediments for an extended time period.

Concentrations of PAHs in sediments are controlled by organic matter content and grain size [14-16]. Organic 
matter plays a major role in sorbing PAHs, particularly when its content in sediments is $>0.1 \%$ [17]. The types of organic matter may also affect PAH concentrations in sediments [18]. For example, condensed carbonaceous geosorbents, such as black carbon, coal and char, have greater sorption capabilities compared to natural amorphous organic matter [19]. Humic substances, geopolymers and materials from combustion (soot or black carbon) differ in their capacity for sorption/desorption of PAHs [20]. The role of grain size in PAH sorption is still under debate. Rockne et al. [21] found high PAH concentrations in large size fractions $(>500 \mu \mathrm{m})$, while other studies suggested that high PAH concentrations associate with smaller size fractions [22]. However, Yang et al. [23] suggested that PAHs associate with the low density fraction dominated by plants- and coal-derived debris rather than particle size. Mostafa et al. [24] suggested that the distribution and concentration of PAHs in sediments are determined by their contamination sources rather than the type of sediment.

The northern Gulf of Mexico is a major hub of oil and gas industries in the United States. The offshore areas produce about 1.3 million barrels of crude oil per day, which amounts to $\sim 23 \%$ of the total US production, while the onshore areas account for $40 \%$ of total petroleum refining capacity (www.eia.gov). In addition, this region contains abundant gas hydrate deposits and oil seeps, which have a high potential to release organic contaminants into sediments $[25,26]$. Considering that PAHs account for $10-45 \%$ of total hydrocarbons in crude oil [11,27], and the importance of this region to US fisheries stock and migratory waterfowl [28], it is important to understand the distribution of PAHs in this area. Previous studies showed that high PAH concentrations in shallow Gulf of Mexico sediments $(<20 \mathrm{~m})$ were found in the early 1970 s, when gas and oil production was highest $[25,26,29]$. Wade et al. [30] determined concentrations of trace metals and PAHs in deep Gulf of Mexico sediments, and suggested that PAH levels are associated with drilling operations. However, few studies have compared the PAHs distribution in shallow shelf and marsh sediments from the Gulf of Mexico. In particular, contamination sources and association mechanisms of PAHs in these sediments remain unclear. The goals of this study were to: (1) determine the concentration and composition of PAHs, (2) identify contamination sources of PAHs, and (3) elaborate on the factors controlling distribution, composition and bioavailability of PAHs in surface marsh and shelf sediments in the northern Gulf of Mexico.

\section{Materials and methods Sample collection}

Shelf sediments were collected in the Mississippi River plume off the Louisiana coast ( $<30 \mathrm{~m}$ water depth) using a HYPOX corer [31] in May 2010 (Figure 1). The sampling stations on the shelf were named after the long-term hypoxia study in this area [32,33], including C6, CT, F5, B6, and MRM. Sediments at Sta. MRM (Mississippi River mouth) were also collected in August 2010 and May 2012. Marsh sediments along the adjacent coast were collected in August 2012 using a home-made corer [34], including salt marshes Waveland 1 (W1), Waveland 2 (W2), Marsh Point (MP) and Grand Bay (GB), and freshwater marshes (A, B1, B2). Surface sediments $(0-5 \mathrm{~cm})$ were sectioned and stored in pre-combusted glass jars in a freezer $\left(-20^{\circ} \mathrm{C}\right)$ until analysis. Before analysis, sediments were freeze-dried and ground to achieve homogeneity.

\section{Sediment properties}

Total organic carbon (TOC) and total nitrogen (TN) in sediment were measured by a $\mathrm{CHN}$ elemental analyzer, after the carbonates were removed by acid fuming in a sealed container with concentrated $\mathrm{HCl}$ [35]. The grain size of surface sediments was measured using a BeckmanCoulter laser particle size analyzer (Model LS 13 320). Briefly, $20 \mathrm{~mL}$ deionized water was added to $1 \mathrm{~g}$ of freezedried sediment in a beaker. After soaking for $24 \mathrm{~h}$, the sediment was subjected to vortex mixing for $5 \mathrm{~min}$ to disaggregate loosely-attached aggregates. Neither organic matter nor carbonate was removed for the laser grain size analysis. The size range of detection for this analyzer is from 0.02 to $2000 \mu \mathrm{m}$. Mineral specific surface area was measured after the sediment was muffled overnight at $350^{\circ} \mathrm{C}$, using the one-point BET method on a Quantachrome Monosorb analyzer [36].

\section{PAHs extraction from sediments}

Sixteen priority PAHs listed by the US EPA were analyzed, including naphthalene (Nap), acenaphthene (Ace), acenaphthylene (Acy), fluorene ( $\mathrm{Fl})$, phenanthrene (Phe), anthracene (An), fluoranthene (Flua), pyrene (Pyr), benzo [a] anthracene (BaA), chrysene (Chr), benzo[b]fluoranthene $(\mathrm{BbF})$, benzo[k,j]fluoranthene $(\mathrm{BkF})$, benzo[a]pyrene $(\mathrm{BaP})$, indeno[1-3]pyrene (InP), dibenzo[a,h]anthracene (DBA), and benzo[ghi]perylene (BgP). A mixture of targeted standards for calculation and three deuterated PAHs as the surrogate standards, $\mathrm{D}_{10^{-}}$acenaphthene (Ace- $d_{10}$ ), $\mathrm{D}_{10^{-}}$phenanthrene (Phe- $\left.d_{10}\right)$, and $\mathrm{D}_{12^{-}}$benzo[a]pyrene $\left(\mathrm{BaP}-d_{12}\right)$ (Sigma), were used in this study.

The PAH extraction from sediment followed the protocol of Rhind et al. [37]. Briefly, ca. $1 \mathrm{~g}$ sediment (dry weight) was added with surrogate standards (Ace-d10, Phe-d10, BaP-d12) and $8 \mathrm{~mL}$ ethanoic potassium hydroxide $(1 \mathrm{M})$. The samples were heated to $90^{\circ} \mathrm{C}$ for $8 \mathrm{~h}$. The analytes were extracted by hexane and then purified with a column packed with activated silica gel and topped with $1 \mathrm{~cm}$ anhydrous sodium sulfate. The PAHs were then eluted with dichloromethane/hexane (1:4, v/v). The eluted solution was concentrated and exchanged by hexane to 


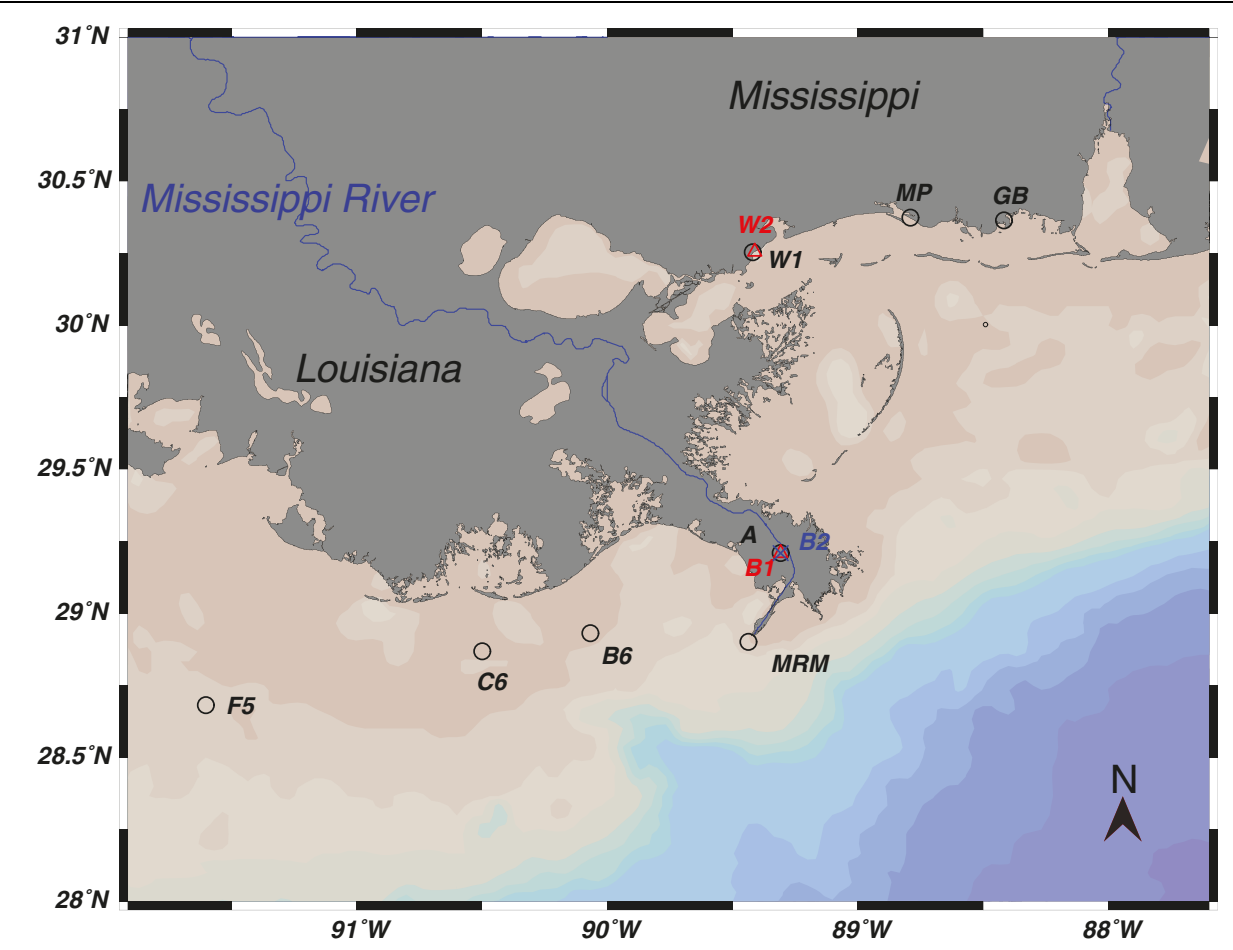

Figure 1 Sampling stations in the northern Gulf of Mexico. Stas. C6, CT, F5 and B6 were from marine shelf; Stas. Waveland H, W1, GB, and MP were from salt marsh; MRM from the Mississippi River mouth; A, B1, B2 were from estuarine freshwater marsh.

$1 \mathrm{~mL}$ with a rotary evaporator, and stored at $4^{\circ} \mathrm{C}$ until further analysis.

\section{Bioavailable PAH extraction from the sediments}

Bioavailable PAHs were extracted from sediments of several stations based on sample availability, including W1, W2, A, B1, MRM, and C6. The extraction protocol followed the study of Voparil and Mayer [38], which mimics the fraction of PAH available to a marine benthic invertebrate such as a polychaete. The animal species to which this protocol was tuned lies at the approximate median of 18 species of deposit-feeder dissolution capability for PAH [39]. Briefly, 10-20 g of sediment was extracted using a cocktail of $15 \mathrm{mM}$ sodium taurocholate and $5 \mathrm{~g} \mathrm{~L}^{-1}$ protein in a Ca-free, artificial seawater matrix. The ratio of sediment to cocktail was 0.25 . The slurry was centrifuged at $4000 \mathrm{rpm}$ for $12 \mathrm{~min}$ and the supernatant was filtered through pre-combusted GF/F filters. PAHs in the filtered solution were spiked with surrogate standard Phe- $d_{10} 20 \mathrm{uL}(10 \mathrm{ng} / \mathrm{uL})$, and serially extracted with $25 \mathrm{~mL}$ DCM for three times. The combined extractions were passed through sodium sulfate, rotovapped, and purified by a self-packed chromatography column (top with $\sim 2 \mathrm{~cm}$ anhydrous sodium sulfate and bottom with $3 \mathrm{~g}$ silica gel), exchanged by hexane to $1 \mathrm{~mL}$ with a rotary evaporator, and stored in a refrigerator at $4^{\circ} \mathrm{C}$ until further analysis.

\section{PAH analysis}

PAHs were analyzed by gas chromatography-mass spectrometry (GC-MS, Shimadzu QP2010 plus). The GC-MS is equipped with a RXi-1MS capillary column (20 $\mathrm{m} \times$ $0.18 \mathrm{~mm}$ i.d., film thickness $0.18 \mu \mathrm{m}$ ), with helium as the carrier gas at a flow rate of $0.8 \mathrm{~mL} \mathrm{~min}{ }^{-1}$, using a selective ion monitoring mode to detect PAHs. The scan ions ranged from 126 to 279 atomic mass units, and the dwell time per ion was 200 milliseconds. The oven temperature was held at $60^{\circ} \mathrm{C}$ for $1 \mathrm{~min}$, increased to $240^{\circ} \mathrm{C}$ at a rate of $10^{\circ} \mathrm{C} \mathrm{min}^{-1}$, and then increased to $280^{\circ} \mathrm{C}$ at a rate of $4^{\circ} \mathrm{C} \mathrm{m^{-1 }}$ and held for $3 \mathrm{~min}$. The temperatures of the injector and detector were $260^{\circ} \mathrm{C}$ and $275^{\circ} \mathrm{C}$, respectively. The injection volume was $1 \mu \mathrm{L}$ with a split ratio of $1 / 20$. All of the 16 PAHs were eluted from 5 to $30 \mathrm{~min}$ in the GC column.

\section{Quality assurance/quality control (QA/QC)}

All analyses were conducted on duplicate samples (except shelf sediments), and the size distribution analysis was conducted on triplicate samples. Three deuterated PAHs (Ace- $d_{10}$, Phe- $d_{10}$, BaP- $d_{12}$ ) were used as surrogates during the extraction for recovery calculation. The average recovery rates of the three surrogates for sediments ranged from $65.2 \%$ to $143.0 \%(n=49)$. The variance of replicate analyses for bioavailable PAHs was $3 \%$ (1 relative SD). The method blank was analyzed by 
the same procedure as the samples, and the background contamination was negligible.

\section{Results}

\section{Sediment characterization}

TOC and TN contents in the marsh sediment ranged from 0.1 to $6.9 \%$, and 0.02 to $0.71 \%$, respectively, both of which were higher compared to shelf sediments, which ranged from $0.6-1.2 \%$ and $0.07-0.11 \%$, respectively (Table 1 ). Temporal variability or spatial heterogeneity was significant for TOC in MRM sediments, ranging from 1\% (May) to $13.9 \%$ (August). Atomic $\mathrm{C} / \mathrm{N}$ ratios of sedimentary OM varied from 7.2 to 19.5 , with higher values in marsh than shelf sediments. This pattern is expected because of the dominant marsh plant input to marsh sediments as compared to algal input to shelf sediments.

The shelf sediments contained $>60 \%$ silt $(4-63 \mu \mathrm{m})$, whereas the marsh sediments contained $>60 \%$ sand $(>63 \mu \mathrm{m})$. Specific mineral surface area in shelf sediments ranged from 13 to $16 \mathrm{~m}^{2} \mathrm{~g}^{-1}$, typical ranges found in coastal sediments [36]. The specific surface area of shelf sediments was relatively uniform, suggesting the homogeneity of mineral grains due to extended physical dynamics on the shelf. In contrast, surface areas in marsh sediments were lower and were more variable, as expected from the coarser grains, ranging from 0.9 to $8.2 \mathrm{~m}^{2} \mathrm{~g}^{-1}$. The wide range of surface area in the marsh sediment implies high heterogeneity of mineral grains in marsh sediments. For example, silts and clays accounted for $40 \%$ at Sta. B2 but $<10 \%$ at Sta. B1, even though these two stations are only $3.2 \mathrm{~km}$ apart.
Concentrations and compositions of PAHs in sediments

PAH concentrations were higher in marsh sediments (229-379 $\mathrm{ng} \mathrm{g}^{-1}$ ) than shelf sediments (175-244 $\mathrm{ng} \mathrm{g}^{-1}$ ). Highest PAH concentrations occurred at Sta. MRM (441-856 $\mathrm{ng} \mathrm{g}^{-1}$ ), with concentrations in May 2010 up to 2 times higher than in August 2010 and May 2012 (Figure 2). This large variation indicates an impact of contaminant source and strong physical dynamics at the river mouth. Similarly, PAH concentrations in the Mississippi River marsh sediments exhibited large differences. Stations B1 and B2 are within $3.2 \mathrm{~km}$ distance, but their PAH concentrations differed by four fold at Stations B1 and B2 (Figure 2). This difference is likely due in part to the fact that these areas represent newly forming land, which emerged following the Great Mississippi River flood of 2011. Such newly formed land often features a diversity of sediment types and depositional environments located within close proximity to each other [40].

High PAH concentrations in sediments may be expected based on the significant level of petroleum and gas activities in the area. The concentrations measured (229-379 $\mathrm{ng} \mathrm{g}^{-1}$ ) were lower than the ERL (effects rangelow) value established by Long et al. (1995) [41], suggesting that these PAH levels present little risk to organisms in this area. These concentrations were generally consistent with previous studies from this area [29,30], and much lower than highly industrialized estuaries such as the Lenga (290-6118 $\mathrm{ng} \mathrm{g}^{-1}$ ) [42], Patos Lagoon (38-11780 ng g ${ }^{-1}$ ) [43], and Jiulong River (280-1074 $\mathrm{ng} \mathrm{g}^{-1}$ ) [44]. Shelf sediments were collected during the Deepwater Horizon oil spill and marsh sediments were collected two years after the spill, so hydrocarbon contamination might be expected.

Table 1 Sediment properties for each station (nd: not detected)

\begin{tabular}{cccccccc}
\hline Sampling station & TOC (\%) & TN (\%) & C/N & \multicolumn{3}{c}{ Sediments fractions (\%) } & Surface \\
\cline { 5 - 6 } area $\left(\mathbf{m}^{2} / \mathbf{g}\right)$
\end{tabular}

TOC and TN represent total organic carbons and total nitrogen, respectively. Silt and clay fractions decreased from shelf sediments to coastal sediments, as well as surface area. The TOC\% and C/N exhibited opposite patterns. 


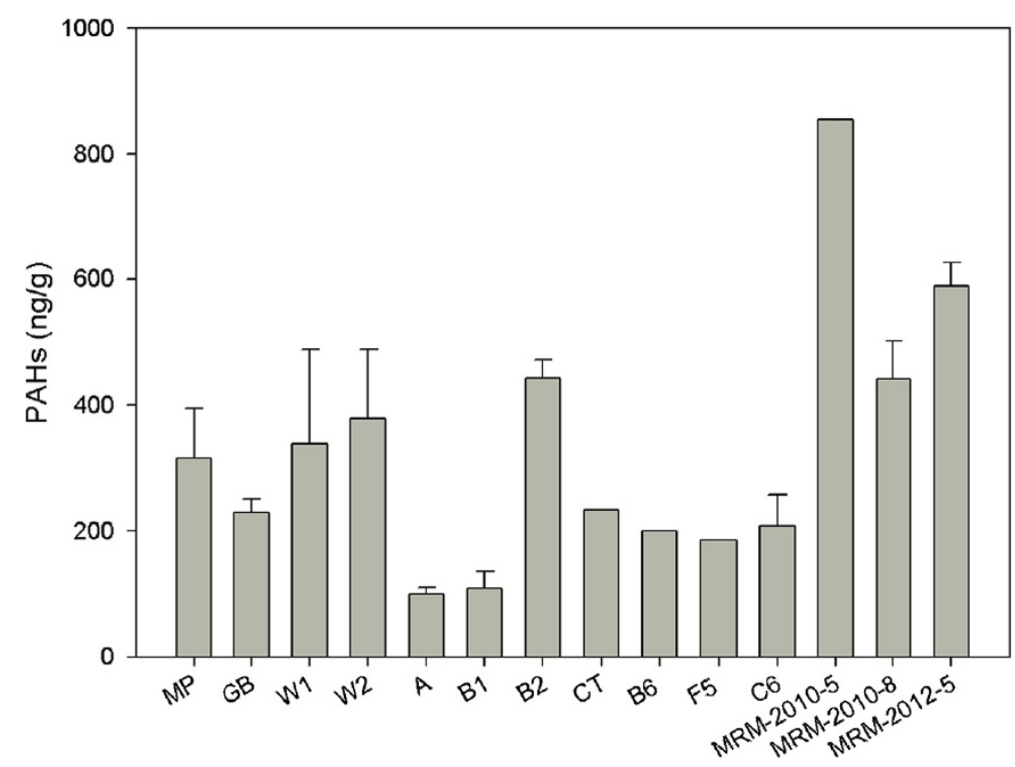

Figure 2 Total PAH concentrations in sediments from northern Gulf of Mexico. Error bars represent one standard deviation of duplicate samples.

Low PAH concentrations detected in the shelf sediments suggested that they were not contaminated to a detectable degree, consistent with the fact that oil mousses and slicks were observed only at the sea surface [45]. Salt marshes in this region may have been impacted by the oil, but two years of weathering can significantly degrade the characterizable hydrocarbons [46]. At the Waveland marshes, Shoreline Cleanup and Assessment Teams (SCAT) reports indicate these sites received, at their maximum (April 13, 2011 report), little or no oiling (gomex.erma.noaa.gov). In contrast, the Mississippi River mouth stations A, B1 and B2 were not oiled during the Deepwater Horizon oil spill, as these areas emerged following a massive flood of 2011, and were not extant during the spill [47]. Overall, we found little impact of the Deepwater Horizon oil spill on PAH concentrations in the sediments collected.

Compositionally, PAHs with 3-4 rings accounted for more than $50 \%$ of the total PAHs at all stations except Stas. A and B1, where 2-ring PAHs dominated. However, compositions of other PAHs varied among the sampling areas. Proportions of 2-ring PAHs were higher than 5-6ring PAHs in shelf sediments, opposite to that in marsh sediments (Figure 3). Compositions of PAHs exhibited differences even among the adjacent stations in marsh sediments. For example, Sta. B1 contained a higher proportion of 2-ring PAHs $(>40 \%)$ and a lower proportion of 5-6-ring PAHs (<20\%), while Sta. B2 contained a lower proportion of 2-ring PAHs $(<20 \%)$ and more 5-6-ring PAHs (>35\%).

\section{Bioavailable PAHs}

The proportions of bioavailable PAHs in total PAHs were low, ranging from 0.02 to $0.06 \%$ - a range similar to those found for sediments in other areas [38]. The highest proportion of bioavailable PAHs was found in Sta. A sediment, with low TOC content $(0.11 \%)$ and small specific surface area $\left(1.2 \mathrm{~m}^{2} \mathrm{~g}^{-1}\right)$. PAHs in Sta. MRM and Sta. C6 sediments exhibited the lowest bioavailable proportions (0.02\%). The bioavailable proportions of PAHs in marsh sediments were generally $>0.02 \%$, higher than those in shelf sediments. The types of bioavailable PAHs differed among the sediments. For example, only 7 PAHs were measurably bioavailable in Sta. MRM sediments, as compared to 12 PAHs in Sta. B1 sediments. Although the bioavailable fractions of certain low-molecular-weight PAHs were higher, such as Acy in Sta. W2 sediment (40\%) and Ace in Sta. B1 and Sta. C6 sediments (33\% and 31\%, respectively), bioavailable proportions of most PAHs were $<0.05 \%$. The bioavailability of PAHs generally decreased with increasing molecular weight (Figure 4), although the bioavailable proportions of Nap were smaller than those of 3- or 4-ring PAHs at certain stations, such as Stas. A and W2.

\section{Discussion}

\section{Factors affecting PAH concentrations}

Higher PAH concentrations found in the marsh compared to shelf sediments may provide insight into factors affecting PAH concentrations. Certain sediment properties can affect $\mathrm{PAH}$ distribution and concentrations, such as TOC and/or clay content [24]. Specifically, PAH concentrations tend to be higher in sediments with higher TOC contents due to the high sorption capacity of OM [48]. However, a poor correlation was found between TOC and $\mathrm{PAH}$ concentrations in this study (Figure $5 \mathrm{a}, \mathrm{R}=0.30$ ). $\mathrm{PAH}$ concentrations were positively correlated with $\mathrm{C} / \mathrm{N}$ 


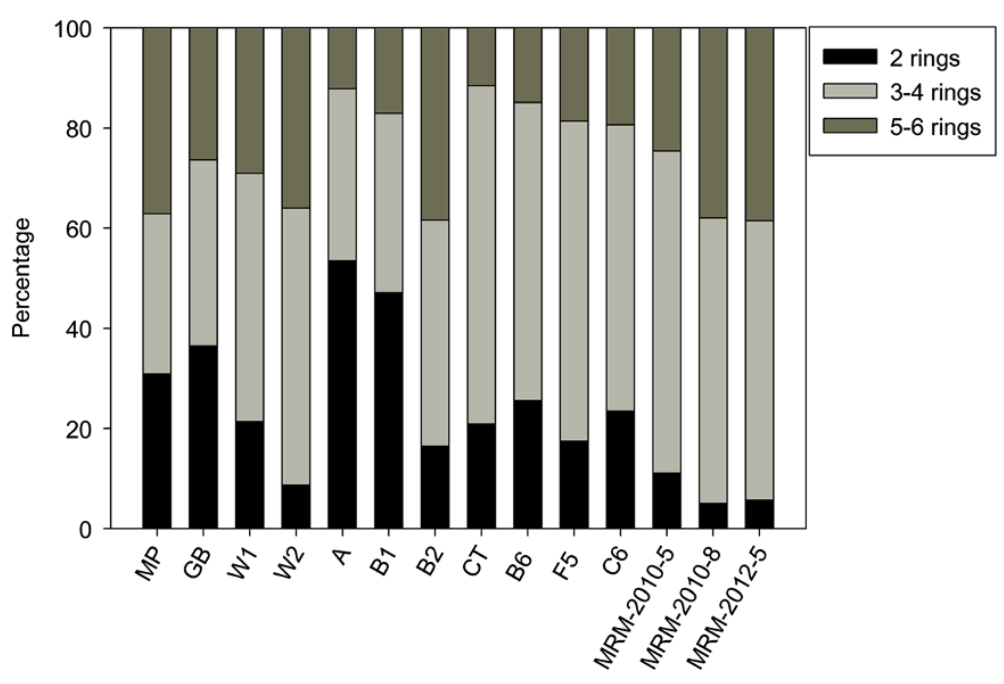

Figure 3 The distribution of PAHs with 2, 3-4 and 5-6 rings in sediments.

ratios of sedimentary OM (Figure 5b, $\mathrm{R}=0.75, \mathrm{p}<0.01$ ). Note that the MRM sediment in May 2010 was not included in this particular analysis because of the exceptionally high $\mathrm{PAH}$ concentration, which may be due to upstream effluents. There should be a large amount of contaminants from upstream as the Mississippi River drains the third largest watershed on earth, with much of that land devoted to industry and agriculture $[33,49]$. $\mathrm{C} / \mathrm{N}$ ratios can be used to distinguish the source of $\mathrm{OM}$ [50]: higher $\mathrm{C} / \mathrm{N}$ ratios $(13.7 \pm 4.3)$ in the marsh sediments indicates a mixture of vascular plant and marine algal sources, whereas the lower $\mathrm{C} / \mathrm{N}$ ratios in shelf sediments

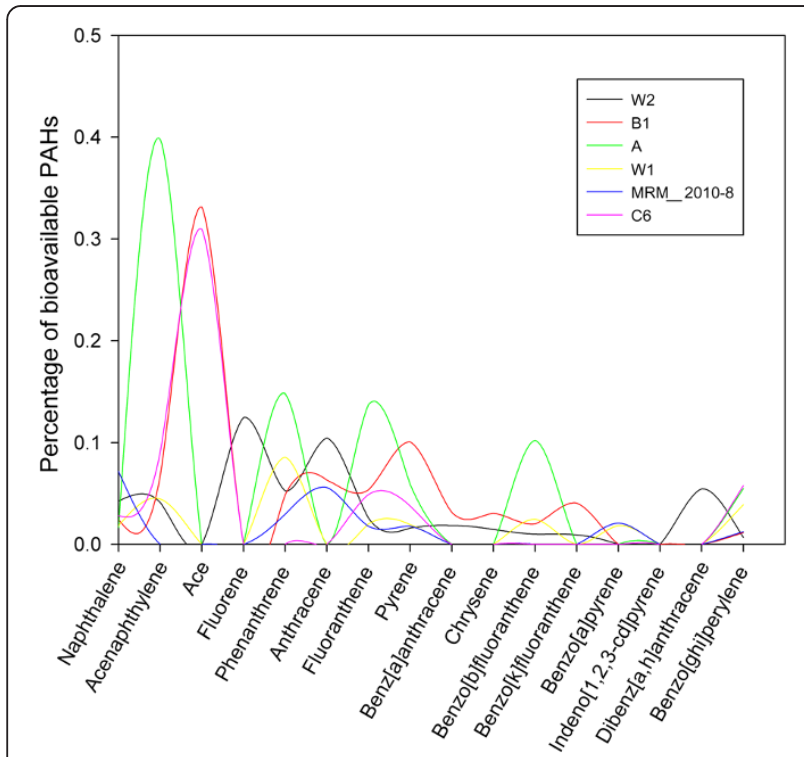

Figure 4 Distribution of bioavailable proportions of PAHs, expressed as percentage of total extractable contents.
$(9.6 \pm 0.9)$ indicates that organic matter was derived more from phytoplankton. The positive relationship between $\mathrm{PAH}$ concentrations and $\mathrm{C} / \mathrm{N}$ ratios suggests that PAHs preferentially attach to terrestrial and marine grass $\mathrm{OM}$ than to marine algal OM. Terrestrial OM contains more aromatic moieties than marine OM [51,52], so a tight association of terrestrial OM with the aromatic PAHs was expected. It is also possible that soot particles, which are depleted in nitrogen and are strong sorbents for PAHs $[53,54]$, were more abundant in $\mathrm{OM}$ with high $\mathrm{C} / \mathrm{N}$ ratios. If this hypothesis were true, the proportion of soot particles must be high enough to drive up the $\mathrm{C} / \mathrm{N}$ ratios of sedimentary OM. However, combusted sediments (BC) and untreated sediments $(\mathrm{OC}+\mathrm{BC})$ often have similar $\mathrm{C} / \mathrm{N}$ ratios for sediments containing 1-4\% TOC [55], indicating that soot particles cannot drive $\mathrm{C} / \mathrm{N}$ ratios significantly due to their small fractions in total OM. Overall, our results suggest that the type of OM, marine vs. terrestrial, is a major factor affecting PAH concentrations in coastal sediments of the northern Gulf of Mexico.

Mineral surface area affects the distribution of PAHs in sediments, as sorption of PAHs occurs either on mineral surfaces directly or in organic matter coatings on mineral surfaces [56]. Smaller minerals, with high specific surface area, can sorb TOC and organic pollutants, such as PAHs and PCBs $[14,15,57,58]$. However, PAH concentrations in shelf sediments, with finer minerals (silts and clays) and higher specific surface area, were lower than those in marsh sediments with coarser minerals and lower surface areas (Table 1, Figure 2). This pattern suggests that other factors, such as the type of organic matter or contamination source, are more important in controlling $\mathrm{PAH}$ concentrations. This pattern could also be explained by the role of marsh sediments in "biofiltering" 

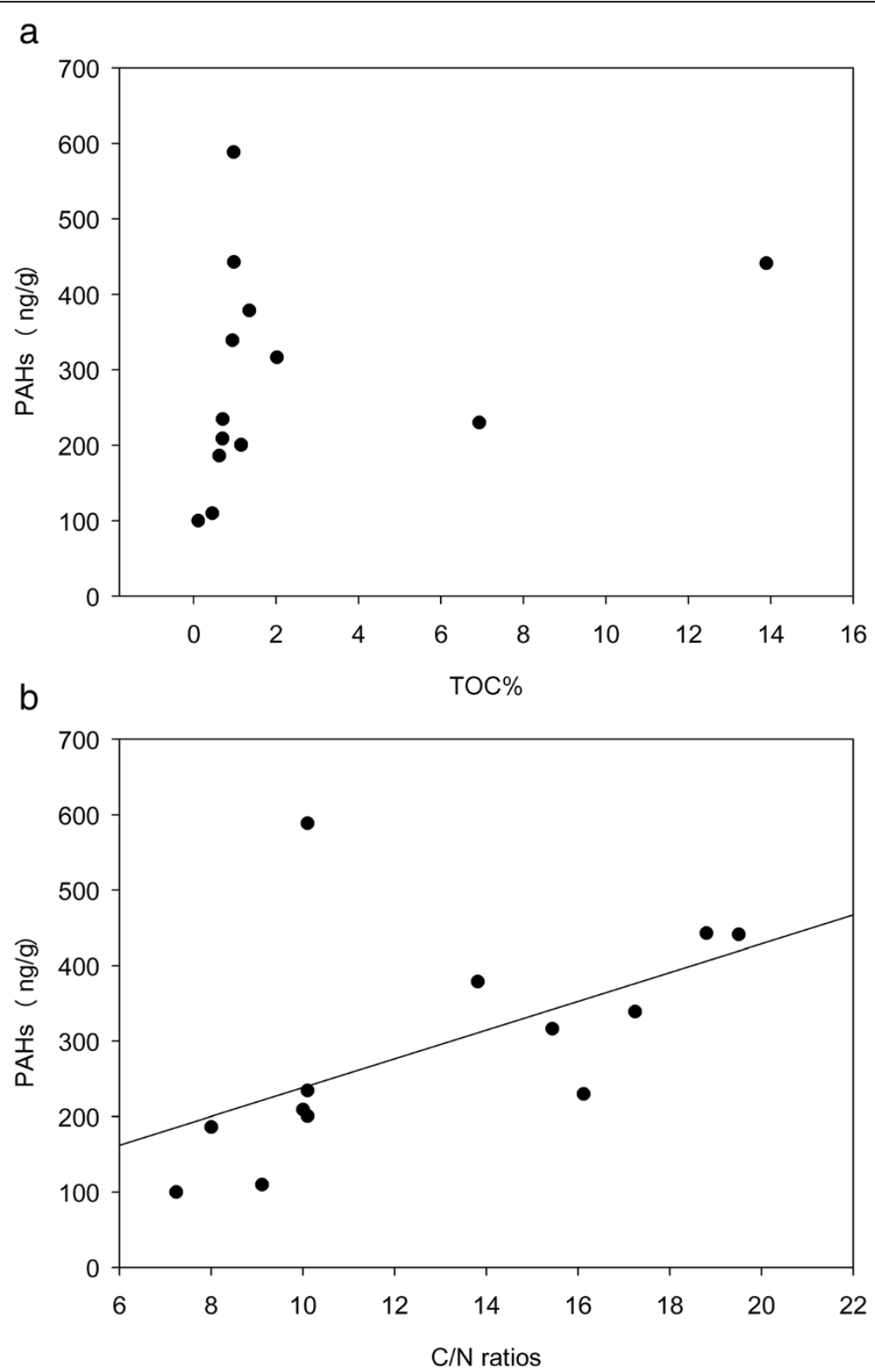

Figure 5 Relationship between PAH concentrations and (a) TOC $(r=0.3)$, and (b) $C / N$ ratios $(r=0.75, p<0.01)$ in sediments. The MRM sediment in May 2010 was excluded due to its exceptionally high PAH concentration.

PAHs before they are exported to shelf sediments [4], even though a major fraction of sediment may be directly exported from river to shelf environments. Concentrations of PAHs did not correlate with specific surface area over all stations, but they did correlate well if only the marsh sediments are considered $(R=0.70, p<0.01$, Figure 6$)$. This result suggests that when the type of OM and the contamination source are similar (terrestrial OM in this case), mineral surface area may be important in controlling the distribution of PAHs. Consistently, our previous study showed that finer fractions contained higher $\mathrm{PAH}$ levels than those coarser fractions after salt marsh sediments from a station in the western Gulf of Mexico were size-fractionated [59].

Insights from PAH compositions: contamination sources and physical dynamics

Composition of PAHs can indicate different contamination sources, including petroleum and low-medium vs. high temperature alteration of organic matter $[13,60]$. To evaluate contamination sources for the PAHs, we applied principal component analysis (PCA) using the 

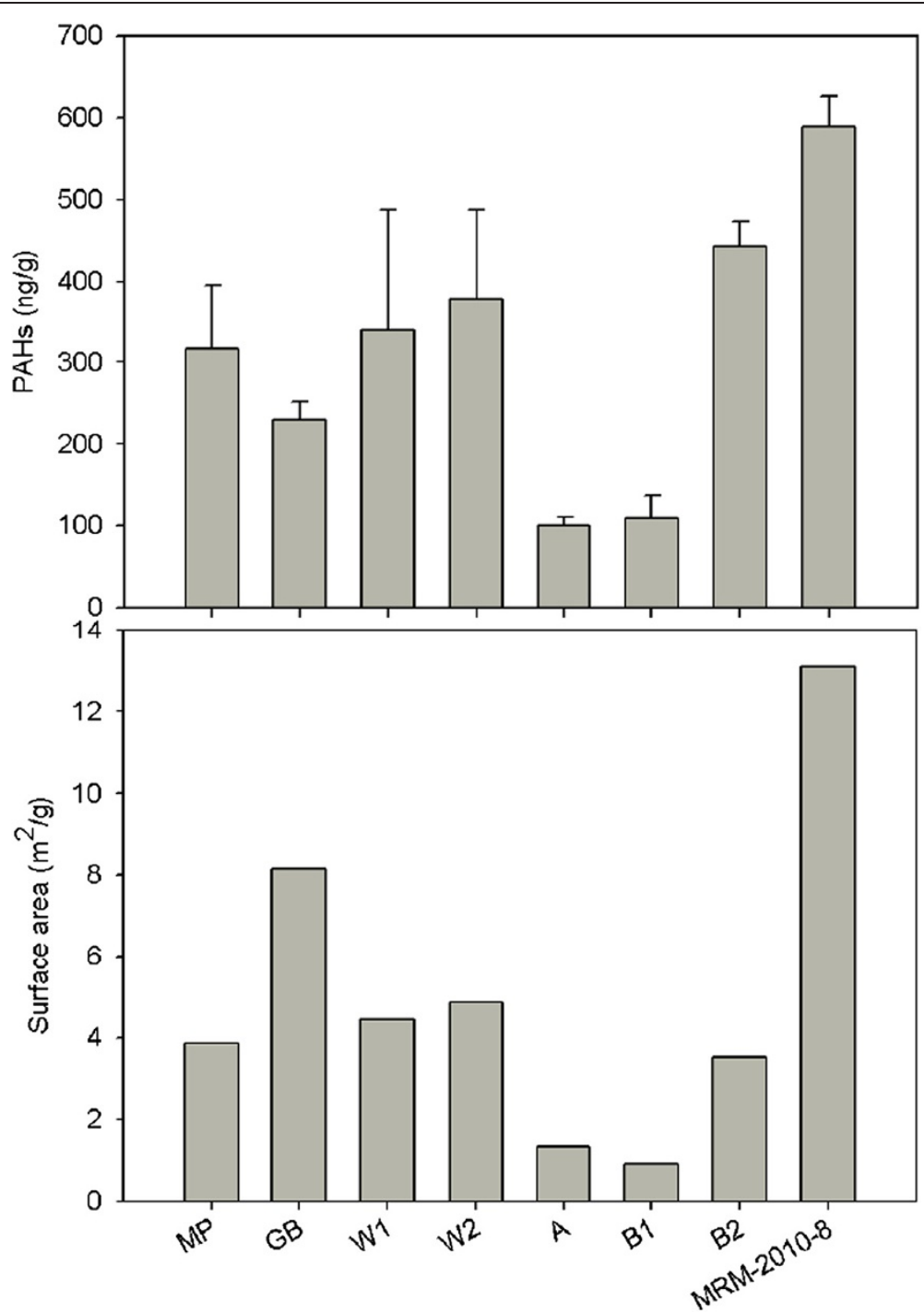

Figure 6 PAH concentrations and specific mineral surface area in marsh sediments.

compositional data [4,61-63]. Principal component 1 (PC1) and PC2 accounted for $61 \%$ and $20 \%$ variance of the data matrix, respectively (Figure 7). From the plot, shelf sediments were well separated from marsh sediments, which were enriched with PAHs with 4-6 rings, including BaA, Chr, BbkF, BaP, BahA and BghiP. These high-molecularweight PAHs are typically from gasoline and diesel combustion [42,64-66]. In contrast, shelf sediments were enriched with low-molecular-weight PAHs, which are abundant in crude oil. These results suggest that petroleum combustion contributes more to the PAHs in marsh sediments, while uncombusted petroleum contributes more to the PAHs in shelf sediments.

Ratios of selected PAH isomers, including Phe/(An + Phe $)$ Flua/(Flua + Pyr $), \mathrm{Chr} /(\mathrm{BaA}+\mathrm{Chr})$ and $\mathrm{InP} /(\mathrm{InP}+$ $\mathrm{BgP})$, can also help to differentiate contamination sources
$[67,68]$. Ratios of InP to 276 (InP and BgP) and Flua to 202 (Flua and Pyr) were applied to our data, because these isomers have great stability [69]. For most sediment samples except Sta. B1, both InP/276 and Flua/202 ratios were between 0.2 and 0.5 and below 0.5 , respectively. This result suggests that PAHs in all the northern Gulf of Mexico sediments were from mixed sources of petroleum and fossil fuel combustion [70], even though combustion sources contribute more to marsh sediments and petroleum contributes more to shelf sediments.

In addition to contamination source, particle size may affect PAH composition [71]. Organic matter in finer particles is often more degraded than that in coarser particles $[72,73]$, so PAHs may sorb differently to particles with different sizes. For example, high-molecular-weight PAHs were found to be more abundant in finer than coarser 


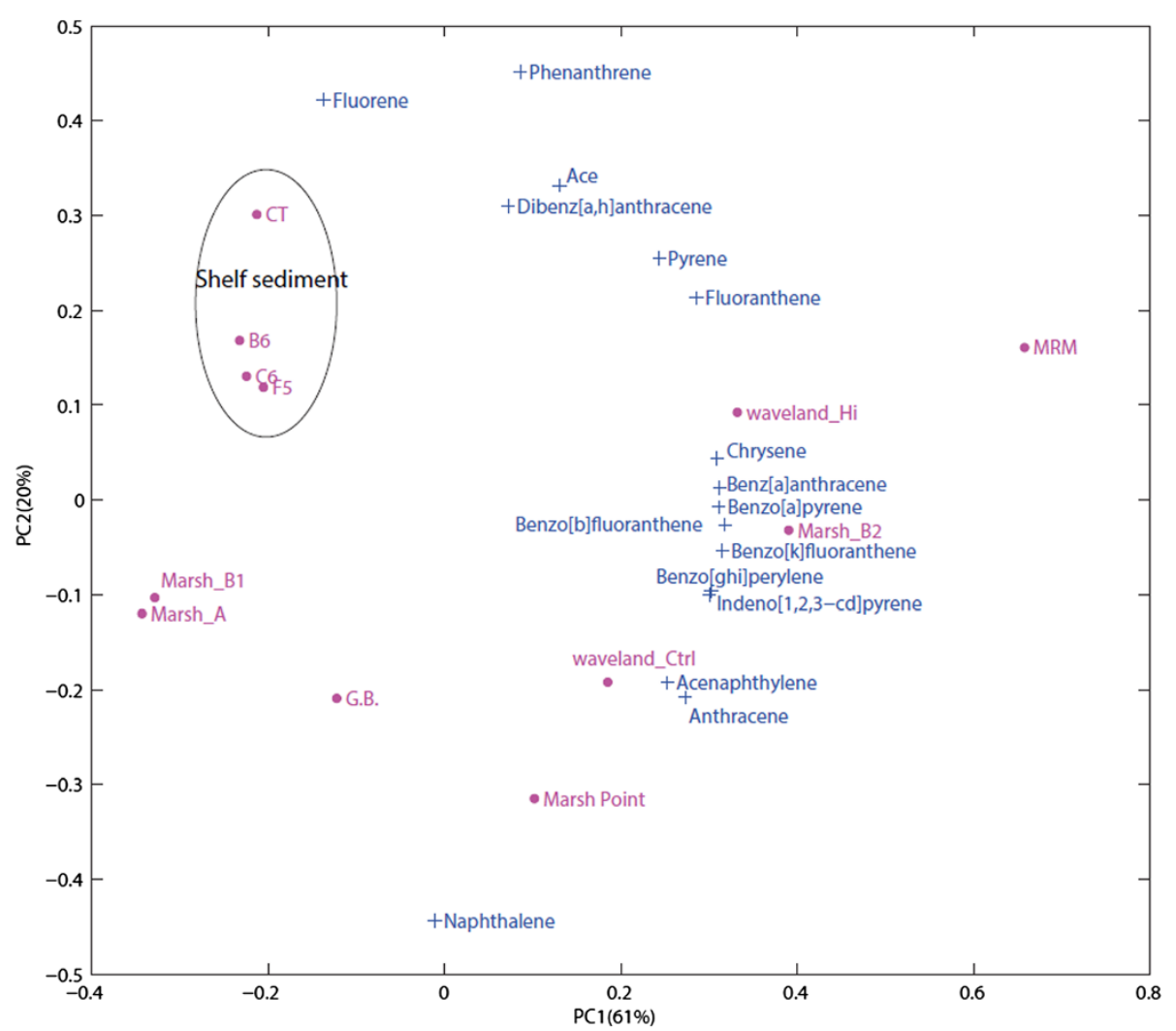

Figure 7 Principal component analysis (PCA) on PAH composition in sediments. PC1 explained $61 \%$ of the variance of the data matrix, and PC2 20\% of the rest. Shelf sediments were clearly separated from marsh sediments.

fractions after salt marsh sediments were size-fractionated [59]. This argument seems to be supported by the different PAH compositions between Sta. B1 and Sta. B2. Sta. B1 contained a higher proportion of 2-ring PAHs $(>40 \%)$ and a lower proportion of 5-6-ring PAHs $(<20 \%)$, while Sta. B2 contained a lower proportion of 2-ring PAHs $(<20 \%)$ and more 5-6-ring PAHs (>35\%) (Figure 7). As these two sites are only $3 \mathrm{~km}$ away from each other and thus expected to have similar contamination sources, this drastic compositional difference suggests that PAHs may have been redistributed within this area by strong physical dynamics, such as freshwater inflows and tidal currents. High-molecularweight PAHs, which are more hydrophobic, may preferentially bind with finer mineral grains rich in degraded $\mathrm{OM}$, and low-molecular-weight PAHs with coarser mineral grains with fresher OM. Such a pattern can be explained by the fact that degraded organic matter is more "glassy" [72,73], and has stronger sorption capability for PAHs with 5-6 rings compared to fresher organic matter in coarser size fractions [74-76].

\section{Bioavailable PAHs}

A large fraction of PAHs is often strongly sorbed to sedimentary OM, so only a small fraction is bioavailabile. The fraction that can be digested by organisms may affect the functioning of coastal ecosystems, so quantifying the bioavailable PAHs is important for risk assessment and bioremediation [77,78]. The bioavailable PAHs here were quantified using a cocktail of sodium taurocholate and protein, as an analog of the digestive fluids in depositfeeding macrofauna [38]. While these bioavailable percentages were very low, it is likely that repeated extractions would have released more PAH [38]. These extractabilities are lower than those in experiments with freshly spiked $\mathrm{PAH}$ in sediment [39], and are likely due to the decrease in extractability that often accompanies aging of PAH in sediment [79].

The percentages of bioavailable PAHs were negatively correlated $(\mathrm{R}=0.88, \mathrm{p}<0.05)$ in sediments with high organic carbon contents, similar to the effect of sedimentary organic carbon concentration on gut fluid extractability of hydrophobic methyl mercury [80]. High contents of OM can compete more effectively with digestive fluids for PAHs, leading to smaller bioavailable fractions [81]. For example, Nam et al. (1998) [81] found that more PAHs are sequestered in sediments with more organic matter [82]. The bioavailability of PAHs may be also influenced by mineral surface area, particularly in sediments with low organic content $[57,83,84]$. Higher fractions of bioavailable PAHs were found in sediments with lower mineral surface 
area in this study, even though an inverse correlation was not significant $(\mathrm{R}=0.71, \mathrm{p}<0.1)$. It is also clear that PAHs with low molecular weights had higher bioavailable percentages than those with high molecular weights (Figure 4). Lower bioavailability for PAHs with more benzene rings indicates the bioavailability of PAHs decreased with their octanol-water partition coefficient $\left(\mathrm{K}_{\mathrm{ow}}\right)$ [85]. Even though the bioavailable fractions only account for $0.05 \%$, more bioavailable PAHs in marsh sediments indicates higher risk to organisms in marshes than those in the shelf sediments.

\section{Conclusion}

In this study we provided baseline data of the PAH distribution in both surface marsh and shelf sediments of the northern Gulf of Mexico, identified contamination sources for the PAHs, and investigated factors controlling concentration and composition of PAHs. The PAH concentrations in the study area were below effects lowrange, ranging from $100-856 \mathrm{ng} \mathrm{g}^{-1}$, indicating little toxicity to organisms. The levels of PAHs followed the trend of $\mathrm{MRM}>$ marsh $>$ shelf sediments. PAHs concentrations were positively correlated with $\mathrm{C} / \mathrm{N}$ ratios of $\mathrm{OM}$, suggesting that PAHs preferentially bind with terrestrial organic matter. PAHs with 3-4 rings were dominant in all the sediments, but the PAH compositions differed between marsh and shelf sediments. The PCA results showed that PAHs in marsh sediments were primarily pyrogenic, while PAHs in shelf sediments were primarily petrogenic. Particle size also affected PAHs compositions, as shown via strong size-composition within small regions. The fraction of bioavailable PAHs was negatively correlated with specific mineral surface area or organic carbon contents in sediments, indicating that a stronger association of PAHs with fine particles decreases their bioavailability.

\section{Competing interests}

The authors declare that they have no competing interests.

\section{Authors' contributions}

ZW carried out most of the analyses, interpreted the results and drafted the manuscript. ZL designed the experiments and helped interpret and draft the manuscript. KX analyzed the grain size distribution of the sediment. LMM analyzed sediment CHN contents and mineral surface area, and extracted the bioavailable PAHs. ZZ helped the PAH analysis. ASK and WW helped sample collection. All authors read and approved the final manuscript.

\section{Acknowledgements}

We are grateful for the assistance from crew of the RN Pelican and Wayne S. Gardner. We thank J. Liu, K. Thornton, Marta Merino Ramos, C. Ramatchandirane and C. Chambers for help with sample collection and analysis. We are grateful for the funding from China Scholarship Council to support Z. Wang during his stay at UTMSI. This project was funded by Texas Higher Education Coordinating Board (THECB\#01859) and Gulf Research Initiative (DROPPS Consortium).

\section{Author details}

'Department of Geography, Northeast Normal University, Changchun, China. ${ }^{2}$ Marine Science Institute, The University of Texas at Austin, Port Aransas, TX, USA. ${ }^{3}$ Department of Oceanography and Coastal Sciences, Louisiana State University, Baton Rouge, LA, USA. ${ }^{4}$ Coastal Studies Institute, Louisiana State
University, Baton Rouge, LA, USA. ${ }^{5}$ School of Marine Sciences, University of Maine, Walpole, ME 04573, USA. ${ }^{6}$ The James Hutton Institute, Aberdeen, UK. ${ }^{7}$ Louisiana Universities Marine Consortium, Chauvin, LA 70344, USA.

${ }^{8}$ Department of Coastal Sciences, Gulf Coast Research Laboratory, The University of Southern Mississippi, Ocean Springs, MS 39564, USA.

Received: 3 September 2013 Accepted: 10 March 2014

Published: 19 March 2014

\section{Reference}

1. Tsapakis M, Dakanali E, Stephanou EG, Karakassis I: PAHs and n-alkanes in Mediterranean coastal marine sediments: aquaculture as a significant point source. J Environ Monitor 2010, 12:958-963.

2. Magi E, Bianco R, lanni C, Di Carro M: Distribution of polycyclic aromatic hydrocarbons in the sediments of the Adriatic Sea. Environ Pollut 2002, 119:91-98.

3. Barakat AO, Mostafa A, Wade TL, Sweet ST, El Sayed NB: Distribution and characteristics of PAHs in sediments from the Mediterranean coastal environment of Egypt. Mar Pollut Bull 2011, 62:1969-1978.

4. Li BH, Feng CH, Li X, Chen YX, Niu JF, Shen ZY: Spatial distribution and source apportionment of PAHs in surficial sediments of the Yangtze Estuary, China. Mar Pollut Bull 2012, 64:636-643.

5. Mastrangelo G, Fadda E, Marzia V: Polycyclic aromatic hydrocarbons and cancer in man. Environ Health Persp 1996, 104:1166-1170.

6. Biro A, Pallinger E, Major J, Jakab MG, Klupp T, Falus A, Tompa A: Lymphocyte phenotype analysis and chromosome aberration frequency of workers occupationally exposed to styrene, benzene, polycyclic aromatic hydrocarbon or mixed solvents. Immunol Lett 2002, 81:133-140.

7. Chen HY, Teng YG, Wang JS: Source apportionment of polycyclic aromatic hydrocarbons (PAHs) in surface sediments of the Rizhao coastal area (China) using diagnostic ratios and factor analysis with nonnegative constraints. Sci Total Environ 2012, 414:293-300.

8. Soclo HH, Garrigues P, Ewald M: Origin of polycyclic aromatic hydrocarbons (PAHs) in coastal marine sediments: Case studies in Cotonou (Benin) and Aquitaine (France) areas. Mar Pollut Bull 2000, 40:387-396.

9. Yunker MB, Perreault A, Lowe CJ: Source apportionment of elevated PAH concentrations in sediments near deep marine outfalls in Esquimalt and Victoria, BC, Canada: Is coal from an 1891 shipwreck the source? Org Geochem 2012, 46:12-37.

10. Fathallah S, Medhioub MN, Kraiem MM: Photo-induced Toxicity of Four Polycyclic Aromatic Hydrocarbons (PAHs) to Embryos and Larvae of the Carpet Shell Clam Ruditapes decussatus. B Environ Contam Tox 2012, 88:1001-1008.

11. Vane $\mathrm{CH}$, Harrison I, Kim AW: Polycyclic aromatic hydrocarbons (PAHs) and polychlorinated biphenyls (PCBs) in sediments from the Mersey Estuary, UK. Sci Total Environ 2007, 374:112-126.

12. Zhang K, Zhang BZ, Li SM, Zeng EY: Regional dynamics of persistent organic pollutants (POPs) in the Pearl River Delta, China: Implications and perspectives. Environ Pollut 2011, 159:2301-2309.

13. Wang CP, Sun HW, Chang Y, Song ZG, Qin XB: PAHs distribution in sediments associated with gas hydrate and oil seepage from the Gulf of Mexico. Mar Pollut Bull 2011, 62:2714-2723.

14. Xia GS, Ball WP: Adsorption-partitioning uptake of nine low-polarity organic chemicals on a natural sorbent. Environ Sci Technol 1999, 33:262-269.

15. Chiou CT, McGroddy SE, Kile DE: Partition characteristics of polycyclic aromatic hydrocarbons on soils and sediments. Environ Sci Technol 1998, 32:264-269.

16. Wang $X C$, Zhang $Y X$, Chen RF: Distribution and partitioning of polycyclic aromatic hydrocarbons (PAHs) in different size fractions in sediments from Boston Harbor, United States. Mar Pollut Bull 2001, 42:1139-1149.

17. Johnson MD, Huang W, Weber WJ: A distributed reactivity model for sorption by soils and sediments. 13. simulated diagenesis of natural sediment organic matter and its impact on sorption/desorption equilibria. Environ Sci Technol 2001, 35:1680-1687.

18. Yang ZF, Wang LL, Niu JF: Sorption Mechanisms of Coexisting PAHs on Sediment Organic Fractions. Environ Toxicol Chem 2011, 30:576-581.

19. Cornelissen G, Breedveld GD, Kalaitzidis S, Christanis K, Kibsgaard A, Oen AMP: Strong sorption of native PAHs to pyrogenic and unburned carbonaceous geosorbents in sediments. Environ Sci Technol 2006, 40:1197-1203.

20. Allen-King RM, Grathwohl P, Ball WP: New modeling paradigms for the sorption of hydrophobic organic chemicals to heterogeneous 
carbonaceous matter in soils, sediments, and rocks. Advances in Water resources 2002, 25:985-1016.

21. Rockne KJ, Shor LM, Young LY, Taghon GL, Kosson DS: Distributed sequestration and release of PAHs in weathered sediment: The role of sediment structure and organic carbon properties. Environ Sci Technol 2002, 36:2636-2644

22. Kim GB, Maruya KA, Lee RF, Lee JH, Koh CH, Tanabe S: Distribution and sources of polycyclic aromatic hydrocarbons in sediments from Kyeonggi Bay, Korea. Mar Pollut Bull 1999, 38:7-15.

23. Yang $Y$, Ligouis B, Pies C, Grathwohl P, Hofmann T: Occurrence of coal and coal-derived particle-bound polycyclic aromatic hydrocarbons (PAHs) in a river floodplain soil. Environ Pollut 2008, 151:121-129.

24. Mostafa AR, Wade TL, Sweet ST, Al-Alimi AKA, Barakat AO: Distribution and characteristics of polycyclic aromatic hydrocarbons (PAHs) in sediments of Hadhramout coastal area, Gulf of Aden, Yemen. J Marine Syst 2009, 78:1-8.

25. Overton EB, Ashton BM, Miles MS: Historical polycyclic aromatic and petrogenic hydrocarbon loading in Northern Central Gulf of Mexico shelf sediments. Mar Pollut Bull 2004, 49:557-563.

26. Brooks JM, Cox HB, Bryant WR, Kennicutt MC, Mann RG, Mcdonald TJ: Association of Gas Hydrates and Oil Seepage in the Gulf-of-Mexico. Org Geochem 1986, 10:221-234.

27. Barata C, Calbet A, Saiz E, Ortiz L, Bayona JM: Predicting single and mixture toxicity of petrogenic polycyclic aromatic hydrocarbons to the copepod Oithona davisae. Environ Toxicol Chem 2005, 24:2992-2999.

28. LACPRA: Louisiana's Comprehensive Master Plan for a Sustainable Coast Louisiana Coastal Protection and Restoration Authority. Baton Rouge 2012.

29. Santschi PH, Presley BJ, Wade TL, Garcia-Romero B, Baskaran M: Historica contamination of PAHs, PCBs, DDTs, and heavy metals in Mississippi River Delta, Galveston Bay and Tampa Bay sediment cores. Mar Environ Res 2001, 52:51-79.

30. Wade TL, Soliman Y, Sweet ST, Wolff GA, Presley BJ: Trace elements and polycyclic aromatic hydrocarbons (PAHs) concentrations in deep Gulf of Mexico sediments. Deep-Sea Res Pt li 2008, 55:2585-2593.

31. Gardner WS, McCarthy MJ, Carini SA, Souza AC, Lijun H, McNeal KS, Puckett MK, Pennington J: Collection of intact sediment cores with overlying water to study nitrogen- and oxygen-dynamics in regions with seasonal hypoxia. Cont Shelf Res 2009, 29:2207-2213.

32. Lin XA, McCarthy MJ, Carini SA, Gardner WS: Net, actual, and potential sediment-water interface $\mathrm{NH}_{4}^{+}$fluxes in the northern Gulf of Mexico (NGOMEX): Evidence for $\mathrm{NH}_{4}^{+}$limitation of microbial dynamics. Cont Shelf Res 2011, 31:120-128.

33. Rabalais NN, Turner RE, Wiseman WJ: Gulf of Mexico hypoxia, aka "The dead zone". Annu Rev Ecol Syst 2002, 33:235-263.

34. Liu Z, Breecker D, Mayer LM, Zhong J: Composition of size-fractioned sedimentary organic matter in coastal environments is affected by difference in physical forcing strength. Org Geochem 2013, 60:20-32.

35. Hedges Jl, Stern JH: Carbon and nitrogen determinations of carbonatecontaining solids. Limnol Oceanogr 1984, 29:657-663.

36. Mayer LM: Surface area control of organic carbon accumulation in continental shelf sediments. Geochim Cosmochim Ac 1994, 58:1271-1284.

37. Rhind SM, Kyle CE, Mackie C, McDonald L: Accumulation of endocrine disrupting compounds in sheep fetal and maternal liver tissue following exposure to pastures treated with sewage sludge. J Environ Monitor 2009, 11:1469-1476

38. Voparil I, Mayer LM: Dissolution of sedimentary polycyclic hydrocarbons (PAHs) into the lugworm's (Arenicola marina) digestive fluids. Environ SC Technol 2000, 34:1221-1228.

39. Mayer LM, Weston DP, Bock MJ: Benzo-a-pyrene and zinc solubilization by digestive fluids of benthic invertebrates - a cross-phyletic study. Environ Sci Technol 2001, 20:1890-1900.

40. Esposito CR, Georgiou IY, Kolker AS: Hydrodynamic and geomorphic controls on mouth bar evolution. Geophys Res Lett 2013, 40:1540-1545.

41. Long ER, Macdonald DD, Smith SL, Calder FD: Incidence of adverse biological effects within ranges of chemical concentrations in marine and estuarine sediments. Environ Manage 1995, 19:81-97.

42. Pozo K, Perra G, Menchi V, Urrutia R, Parra O, Rudolph A, Focardi S: Levels and spatial distribution of polycyclic aromatic hydrocarbons (PAHs) in sediments from Lenga Estuary, central Chile. Mar Pollut Bull 2011, 62:1572-1576.

43. Medeiros PM, Bicego MC, Castelao RM, Del Rosso C, Fillmann G, Zamboni AJ: Natural and anthropogenic hydrocarbon inputs to sediments of Patos Lagoon Estuary, Brazil. Environ Int 2005, 31:77-87.
44. Tian Y, Liu HJ, Zheng TL, Kwon KK, Kim SJ, Yan CL: PAHs contamination and bacterial communities in mangrove surface sediments of the Jiulong River Estuary, China. Mar Pollut Bull 2008, 57:707-715.

45. Liu Z, Liu J, Zhu Q, Wu W: The weathering of oil after the Deepwater Horizon oil spill: insights from the chemical composition of the oil from the sea surface, salt marshes and sediments. Environ Res Lett 2012, 7:035302.

46. Liu Z, Liu J: Evaluating bacterial community structures in oil collected from the sea surface and sediment in the northern Gulf of Mexico after the Deepwater Horizon oil spill. MicrobiologyOpen 2013, 2:492-504.

47. Kolker AS, Miner MD, Weathers HD: Depositional dynamics in a river diversion receiving basin: The case of the West Bay Mississippi River Diversion. Estuar Coast Shelf Sci 2012, 106:1-12.

48. Notar M, Leskovs H, Faganeli J: Composition, distribution and sources of polycyclic aromatic hydrocarbons in sediments of gulf of Trieste, Northern Adriatic Sea. Mar Pollut Bull 2001, 42:36-44.

49. Milliman JD, Meade $\mathrm{RH}$ : World-wide delivery of sediment to the oceans. J Geol 1983, 91:1-21.

50. Meyers PA: Preservation of elemental and isotopic source identification of sedimentary organic matter. Chem Geol 1994, 114:289-302.

51. Hedges Jl, Hatcher PG, Ertel JR, Meyersschulte KJ: A comparison of dissolved humic substances from seawater with Amazon River counterparts by C-13-NMR spectrometry. Geochim Cosmochim Ac 1992, 56:1753-1757

52. Liu Z, Sleighter RL, Zhong J, Hatcher PG: The chemical changes of DOM from black waters to coastal marine waters by HPLC combined with ultrahigh resolution mass spectrometry. Estuar Coast Shelf Sci 2011, 92:205-216.

53. Yang $Y$, Ligouis B, Pies C, Achten C, Hofmann T: Identification of carbonaceous geosorbents for $\mathrm{PAHs}$ by organic petrography in river floodplain soils. Chemosphere 2008, 71:2158-2167.

54. Naes K, Oug E: The distribution and environmental relationships of polycyclic aromatic hydrocarbons (PAHs) in sediments from Norwegian smelter-affected fjords. Chemosphere 1998, 36:561-576.

55. Accardi-Dey A, Gschwend PM: Assessing the combined roles of natural organic matter and black carbon as sorbents in sediments. Environ Sci Technol 2002, 36:21-29.

56. Warren N, Allan IJ, Carter JE, House WA, Parker A: pesticides and other micro-organic contaminants in freshwater sedimentary envirnments - a review. App/ Geochem 2003, 18:159-194.

57. Russell M, Webster L, Walsham P, Packer G, Dalgarno EJ, Mclntosh AD, Fryer RJ, Moffat CF: Composition and concentration of hydrocarbons in sediment samples from the oil producing area of the East Shetland Basin, Scotland. J Environ Monitor 2008, 10:559-569.

58. Ruiz-Fernandez AC, Sprovieri M, Piazza R, Frignani M, Sanchez-Cabeza JA Feo ML, Bellucci LG, Vecchiato M, Perez-Bernal LH, Paez-Osuna F: Pb-210derived history of PAH and PCB accumulation in sediments of a tropical inner lagoon (Las Matas, Gulf of Mexico) near a major oil refinery. Geochim Cosmochim Ac 2012, 82:136-153.

59. Wang ZC, Liu ZF, Liu M, Xu KH: Impact of drying on the rapid release of polycyclic aromatic hydrocarbons from salt marsh sediments in South Texas. Org Geochem: USA; 2013. in review.

60. Zaghden H, Kallel M, Elleuch B, Oudot J, Saliot A: Sources and distribution of aliphatic and polyaromatic hydrocarbons in sediments of Sfax, Tunisia, Mediterranean Sea. Mar Chem 2007, 105:70-89.

61. Simcik MF, Eisenreich SJ, Lioy PJ: Source apportionment and source/sink relationships of PAHs in the coastal atmosphere of Chicago and Lake Michigan. Atmos Environ 1999, 33:5071-5079.

62. Ingalls $A E$, Liu ZF, Lee $C$ : Seasonal trends in the pigment and amino acid compositions of sinking particles in biogenic $\mathrm{CaCO}_{3}$ and $\mathrm{SiO}_{2}$ dominated regions of the Pacific sector of the Southern Ocean along 170 degrees W. Deep-Sea Res Pt I 2006, 53:836-859.

63. Wang ZC, Liu ZF, Yang Y, Li T, Liu M: Distribution of PAHs in tissues of wetland plants and the surrounding sediments in the Chongming wetland, Shanghai, China. Chemosphere 2012, 89:221-227.

64. Harrison RM, Smith DJT, Luhana L: Source apportionment of atmospheric polycyclic aromatic hydrocarbons collected from an urban location in Birmingham, UK. Environ Sci Technol 1996, 30:825-832.

65. May WE, Wise SA: Liquid-Chromatographic Determination of Polycyclic Aromatic Hydrocarbons in Air Particulate Extracts. Anal Chem 1984, 56:225-232.

66. Li CK, Kamens RM: The Use of Polycyclic Aromatic-Hydrocarbons as Source Signatures in Receptor Modeling. Atmos Environ a-Gen 1993, 27:523-532. 
67. Yunker MB, Macdonald RW: Composition and Origins of Polycyclic Aromatic-Hydrocarbons in the Mackenzie River and on the Beaufort Sea Shelf. Arctic 1995, 48:118-129.

68. Barakat AO, Mostafa A, Wade TL, Sweet ST, El Sayed NB: Distribution and characteristics of PAHs in sediments from the coastal environment of Egypt. Mar Pollut Bull 2011, 62:1969-1978.

69. Yunker MB, Backus SM, Graf Pannatier E, Jeffries DS, Macdonald RW: Sources and significance of alkane and PAH hydrocarbons in Canadian arctic rivers. Estuar Coast Shelf S 2002, 55:1-31.

70. Yunker MB, Macdonald RW, Vingarzan R, Mitchell RH, Goyette D, Sylvestre S: PAHs in the Fraser River basin: a critical appraisal of PAH ratios as indicators of PAH source and composition. Org Geochem 2002, 33:489-515.

71. Helmstetter M, Alden R III: Release rates of polynuclear aromatic hydrocarbons from natural sediments and their relationship to solubility and octanol-water partitioning. Arch Environ Contam Toxicol 1994, 26:282-291.

72. Leboeuf EJ, Weber WJ: A distributed reactivity model for sorption by soils and sediments. 8. Sorbent organic domains: Discovery of a humic acid glass transition and an argument for a polymer-based model. Environ Sci Technol 1997, 31:1697-1702.

73. Xing BS, Pignatello JJ: Dual-mode sorption of low-polarity compounds in glassy poly(vinyl chloride) and soil organic matter. Environ Sci Technol 1997, 31:792-799.

74. Jackson CR, Vallaire SC: Microbial activity and decomposition of fine particulate organic matter in a Louisiana cypress swamp. I N Am Benthol Soc 2007, 26:743-753.

75. Xia GS, Pignatello J: Detailed sorption isotherms of polar and apolar compounds in a high-organic soil. Environ Sci Technol 2001, 35:84-94.

76. Talley JW, Ghosh U, Tucker SG, Furey JS, Luthy RG: Particle-scale understanding of the bioavailability of PAHs in sediment. Environ Sci Technol 2002, 36:477-483.

77. Ehlers LJ, Luthy RG: Peer Reviewed: Contaminant bioavailability in soil and sediment. Environ Sci Technol 2003, 37:295A-302A.

78. Hinga KR: Degradation rates of low molecular weight PAH correlate with sediment TOC in marine subtidal sediments. Mar Pollut Bull 2003, 46:466-474.

79. Kraaj RH, Tolls J, Sijm D, Comelissen G, Heikens A, Belfrold A: Effects of contact time on the sequestration and bioavailability of different classes of hydrophobic organic chemicals to benthic oligochaetes(Tubificidae). Environ Toxicol Chem 2002, 21:7520759.

80. Lawrence AL, McAloon KM, Mason RP, Mayer LM: Intestinal solubilization of particle-associated organic and inorganic mercury as a measure of bioavailability to benthic invertebrates. Environ Sci Technol 1999, 33:1871-1876.

81. Nam K, Chung N, Alexander M: Relationship between organic matter content of soil and the sequestration of phenanthrene. Environ $\mathrm{SCi}$ Technol 1998, 32:3785-3788.

82. Cui XY, Hunter $W$, Yang $Y$, Chen $Y X$, Gan J: Biodegradation of pyrene in sand, silt and clay fractions of sediment. Biodegradation 2011, 22:297-307.

83. Yang Y, Hunter W, Tao S, Gan J: Microbial Availability of Different Forms of Phenanthrene in Soils. Environ Sci Technol 2009, 43:1852-1857.

84. Thorsen WA, Cope WG, Shea D: Bioavailability of PAHs: Effects of Soot Carbon and PAH Source. Environ Sci Technol 2004, 38:2029-2037.

85. Berrojalbiz N, Lacorte S, Calbet A, Saiz E, Barata C, Dachs J: Accumulation and Cycling of Polycyclic Aromatic Hydrocarbons in Zooplankton. Environ Sci Technol 2009, 43:2295-2301.

doi:10.1186/1467-4866-15-2

Cite this article as: Wang et al:: Concentrations and sources of polycyclic aromatic hydrocarbons in surface coastal sediments of the northern Gulf of Mexico. Geochemical Transactions 2014 15:2.

\section{Submit your next manuscript to BioMed Central and take full advantage of:}

- Convenient online submission

- Thorough peer review

- No space constraints or color figure charges

- Immediate publication on acceptance

- Inclusion in PubMed, CAS, Scopus and Google Scholar

- Research which is freely available for redistribution

Submit your manuscript at www.biomedcentral.com/submit
C Biomed Central 